\title{
Studi Kasus Pengembangan Wirausaha Berbasis Teknologi (Technopreneurship) di Provinsi Gorontalo
}

\author{
Herwin Mopangga \\ Fakultas Ekonomi dan Bisnis, Universitas Negeri Gorontalo \\ Jl. Jend. Sudirman No. 6 Kec. Kota Tengah Kota Gorontalo 96128 \\ E-Mail: herwin@ung.ac.id
}

\begin{abstract}
This study aims to describe the technology based entrepreneurial activity and non-technopreneurship, to elaborate the efforts to improve students' and graduates' interest to be the doers of technopreneurship, and to compile a document which will be the direction of development to lead technopreneurship in Gorontalo Province. This study used qualitative approach, the data collected by observation, interview, questionnaire and documentation, that located in 6 regencies/city in the Province of Gorontalo. This study concludes that, Low competitiveness of the product by small and medium business in Gorontallo Province is caused by limited technology mastery among entrepreneurs. If there are any technological innovations, it's temporally only for exhibition purpose in regional and national scale, not to enhance the quality of products, diversification and efficiency in short-term, as well as sustainable increased of production, their income increased, and or business extension profit in the long-term. Technopreneurship development that partnership by State University of Gorontalo (UNG) and The Regency of North Gorontalo is the best practice to extend and strengthen technopreneurs in the region. Students interest in entrepreneurship can be increased by research based learning and student centered learning.
\end{abstract}

Keywords: small and medium business, technopreneurship, entrepreneurship, technology.

\begin{abstract}
ABSTRAK
Penelitian ini bertujuan menjelaskan kegiatan wirausaha berbasis teknologi (technopreneurship) dan non-technopreneurship, upaya meningkatkan minat mahasiswa dan lulusan perguruan tinggi menjadi pelaku technopreneurship serta menyusun dokumen arah pengembangan technopreneurship di Provinsi Gorontalo. Penelitian studi kasus ini menggunakan pendekatan kualitatif deskriptif, pengumpulan data melalui observasi, wawancara, kuisioner dan dokumentasi, berlokasi di 6 kabupaten/kota di Provinsi Gorontalo. Penelitian ini menyimpulkan; Rendahnya daya saing produk UMKM Provinsi Gorontalo disebabkan masih rendahnya penguasaan teknologi dikalangan pelaku usaha. Bila ada inovasi teknologi sifatnya temporer, hanya untuk keperluan pameran/eksebisi ditingkat regional dan nasional, bukan untuk peningkatan mutu produk, diversifikasi dan efisiensi dalam jangka pendek maupun peningkatan produksi secara berkelanjutan, peningkatan omzet, laba serta perluasan usaha dalam jangka panjang. Pengembangan technopreneurship kemitraan UNG - Gorontalo Utara (padi organik) merupakan best practice untuk memperluas dan memperkuat technopreneur unggul di daerah. Minat mahasiswa berwirausaha dapat ditingkatkan melalui pembelajaran berbasis riset dan berpusat pada mahasiswa.
\end{abstract}

Kata Kunci: UMKM, technopreneurship, wirausaha, teknologi. 


\section{PENDAHULUAN}

Krisis ekonomi Indonesia yang berkepanjangan menyebabkan makin terbatasnya kesempatan kerja terutama bagi lulusan perguruan tinggi. Pengangguran terbuka di Indonesia tahun 2012 berjumlah 7,61 juta jiwa $(6,32 \%)$ dan $10 \%$ di antaranya adalah sarjana. Data tersebut mendukung pernyataan Organisasi Pekerja Internasional (ILO) bahwa sebagian dari jumlah pengangguran Indonesia adalah lulusan perguruan tinggi (Nasrun, 2010; Setiadi, 2008; dan Niode, 2007). Kondisi bisa semakin memburuk dengan pemberlakuan Masyarakat Ekonomi ASEAN 2015 yang akan mengakibatkan lulusan perguruan tinggi Indonesia harus bersaing dengan lulusan luar negeri khususnya di kawasan Asia Tenggara (Kemendag RI, 2014).

Industrialisasi di Indonesia dengan strategi industri substitusi impor dan berorientasi ekspor ternyata menjadi penyebab timbulnya kesenjangan pendapatan antar sektor dan antar daerah (sectoral and spatial disparity). Tipisnya keterkaitan sektor industri dan pertanian membuat industri modern dalam posisi terasing dari ekonomi rakyat dan menghambat tumbuhnya pelaku usaha sektor informal pertanian tradisional yang memanfaatkan inovasi teknologi. Karena itu perlu adanya revisi kebijakan strategi pengembangan industri di Indonesia dengan menekankan permintaan efektif dalam negeri melalui sektor pertanian (Agricultural Demand-Led Industrialization/ADLI) (Mopangga, 2008:38).

Penciptaan wirausaha (entrepreneur) menjadi alternatif solusi atas berbagai masalah di masyarakat seperti kemiskinan dan kesenjangan sosial, meningkatnya pengangguran usia produktif dan menipisnya cadangan pasokan energi, yang kesemuanya menuntut adanya tindakan kreatif dan inovatif. Jiwa kewirausahaan bukan hanya sebatas kecerdasan akademik dan keterampilan menghasilkan produk tetapi juga jiwa dinamis dalam menangkap tantangan dan resiko kemudian mengubahnya menjadi peluang dan potensi pertumbuhan (Soegoto, 2009).

Suatu bangsa akan maju dan sejahtera bila jumlah entrepreneur-nya minimal 2\% dari total penduduk. Saat ini, ketika Amerika Serikat sudah memiliki 11,5 hingga $12 \%$, Singapura 7\%, serta Cina dan Jepang
$10 \%$, maka Indonesia baru mencapai $0,24 \%$ dari total 238 jutajiwa, dan itu berarti masih dibutuhkan sekitar 4 juta wirausaha baru. Padahal Indonesia menghasilkan sekitar 700 ribu orang sarjana baru setiap tahunnya dan memiliki kemampuan untuk melipatgandakan pertumbuhan ekonomi, pendapatan total maupun perkapita, menurunkan angka pengangguran dan kemiskinan bilamana secara bertahap namun pasti meningkatkan jumlah wirausaha sukses dengan pemanfaatan teknologi yang tumbuh pesat dewasa ini (Ciputra, 2009).

Technopreneurship berasal dari gabungan kata "technology" dan "entrepreneurship" (Depositario, et al., 2011). Technopreneurship merupakan proses sinergi dari kemampuan yang kuat pada penguasaan teknologi serta pemahaman menyeluruh tentang konsep kewirausahaan (Sosrowinarsidiono, 2010). Sudarsih dalam Prosiding KNIT RAMP-IPB (2013:57) mengemukakan bahwa technopreneurship adalah proses dan pembentukan usaha baru yang melibatkan teknologi sebagai basisnya dengan harapan bahwa penciptaan strategi dan inovasi yang tepat kelak bisa menempatkan teknologi sebagai salah satu faktor untuk pengembangan ekonomi nasional. Pendapat lainnya menyebutkan bahwa technopreneurship adalah proses dalam sebuah organisasi yang mengutamakan inovasi dan secara terus menerus menemukan problem utama organisasi, memecahkan permasalahannya, dan mengimplementasikan cara-cara pemecahan masalah dalam rangka meningkatakan daya saing di pasar global (Okorie, 2014). Technopreneurship menggabungkan antara teknologi dan kewirausahaan.

Dalam konsep technopreneurship, basis pengembangan kewirausahaan bertitik tolak dari adanya invensi dan inovasi dalam bidang teknologi yang tidak sekedar high-tech melainkan aplikasi pengetahuan pada kerja orang (human work) seperti penerapan akuntansi, ekonomi order quantity, pemasaran secara lisan maupun online.

Sambodo (2006) membedakan antara pelaku usaha kecil, enterpreneur tradisional, dan technopreneur dalam atribut motivasi, gaya kepemimpinan, tingkatan inovasi hingga penguasaan pasar, dapat dilihat pada Tabel 1. 
Tabel 1. Perbedaan Usaha Kecil, Enterpreneur Tradisional, dan Technopreneur

\begin{tabular}{|c|c|c|c|}
\hline Aspek & Usaha Kecil & Entrepreneur Tradisional & Technopreneur \\
\hline Motivasi & $\begin{array}{l}\text { - Sumber hidup } \\
\text { - Tingkat keamanan } \\
\text { - Bekerja sendiri } \\
\text { - Ide khusus } \\
\text { - Kepribadian pemilik }\end{array}$ & $\begin{array}{l}\text { - } \text { Motivasi mendominasi } \\
\text { - Ide dan konsep } \\
\text { - Eksploitasi kesempatan } \\
\text { - Akumulasi kekayaan }\end{array}$ & $\begin{array}{l}\text { - Pola pikir revolusioner } \\
\text { - Kompetisi dan risiko } \\
\text { - Sukses dengan teknologi baru } \\
\text { - Finansial, nama harum }\end{array}$ \\
\hline Kepemilikan & Pendiri/rekan bisnis & $\begin{array}{l}\text { - Saham pengendali } \\
\text { - Maksimalisasi keuntungan }\end{array}$ & $\begin{array}{l}\text { - Penguasaan pasar } \\
\text { - Saham kecil dari kue besar } \\
\text { - Nilai perusahaan terus bertambah }\end{array}$ \\
\hline Gaya Manajerial & $\begin{array}{l}\text { - } \quad \text { Trial and error } \\
\text { - } \text { Lebih personal } \\
\text { - Orientasi lokal } \\
\text { - Menghindari risiko } \\
\text { - } \\
\text { Arus kas stabil }\end{array}$ & $\begin{array}{l}\text { - Mengikuti pengalaman } \\
\text { - Profesionalisme } \\
\text { - Resiko pada manajemen }\end{array}$ & $\begin{array}{l}\text { - Pengalaman terbatas } \\
\text { - Fleksibel } \\
\text { - Target strategi global } \\
\text { - Inovasi produk berkelanjutan }\end{array}$ \\
\hline Kepemimpinan & $\begin{array}{l}\text { - Jalan hidup } \\
\text { - Hubungan baik } \\
\text { - Dengan contoh } \\
\text { - Kolaborasi } \\
\text { - Kemenangan kecil }\end{array}$ & $\begin{array}{l}\text { - } \text { Otoritas tinggi } \\
\text { - Kekuatan lobi } \\
\text { - Imbalan untuk kontribusi } \\
\text { - Manajemen baru }\end{array}$ & $\begin{array}{l}\text { - Perjuangan kolektif } \\
\text { - Sukses masa depan visioner } \\
\text { - Membagi kemajuan bisnis } \\
\text { - Menghargai kontribusi dan pencapaian }\end{array}$ \\
\hline Tenaga Kerja & $\begin{array}{l}\text { - Jaminan rendah } \\
\text { - Kekeluargaan } \\
\text { - Risiko tinggi }\end{array}$ & $\begin{array}{l}\text { - Merekrut lokal dan global } \\
\text { - Kompensasi menarik } \\
\text { - Mobilitas rendah }\end{array}$ & $\begin{array}{ll}\text { - } & \text { Multikultural kualitas tinggi } \\
\text { - } & \text { Berasal dari PT ternama dan lembaga riset } \\
\text { - Insinyur muda tertarik IPO, M\&A } \\
\text { - } & \text { Finansial, nama harum }\end{array}$ \\
\hline$R \& D$ dan inovasi & $\begin{array}{l}\text { - } \text { Pempertahankan bisnis } \\
\text { jawab } \\
\text { - Siklus waktu yang lama } \\
\text { - Akumulasi teknologi } \\
\text { sangat kecil }\end{array}$ & $\begin{array}{l}\text { - Bukan prioritas utama, } \\
\text { - Kesulitan mendapatkan } \\
\text { peneliti } \\
\text { - Mengandalkan franchise, } \\
\text { lisensi }\end{array}$ & $\begin{array}{l}\text { - Memimpin dalam riset dan inovasi, IT, } \\
\text { biotek global } \\
\text { - } \text { Akses ke sumber teknologi } \\
\text { - } \text { Bakat sangat tinggi } \\
\text { - } \text { Kecepatan peluncuran produk ke pasar }\end{array}$ \\
\hline $\begin{array}{l}\text { Outsourcing } \\
\text { dan Jaringan } \\
\text { Kerja }\end{array}$ & $\begin{array}{l}\text { - Sederhana } \\
\text { - Lobi bisnis langsung }\end{array}$ & $\begin{array}{l}\text { - Penting tapi sulit } \\
\text { mendapatkan tenaga ahli } \\
\text { - Kemampuan umum } \\
\text { - Tidak selalu tersedia pada } \\
\text { tingkat global }\end{array}$ & $\begin{array}{l}\text { - Pengembangan bersama tim outsourcing } \\
\text { - Banyak penawaran } \\
\text { - Science and technology park }\end{array}$ \\
\hline $\begin{array}{l}\text { Potensial } \\
\text { pertumbuhan }\end{array}$ & $\begin{array}{l}\text { - Siklus ekonomi } \\
\text { - Stabil }\end{array}$ & $\begin{array}{l}\text { Penetrasi nasional cepat, } \\
\text { global lambat } \\
\text { - Pemimpin pasar dalam } \\
\text { waktu singkat dengan } \\
\text { proteksi, monopoli, } \\
\text { oligopoli }\end{array}$ & $\begin{array}{l}\text { - Pasar berubah dengan teknologi baru } \\
\text { - Akuisisi teknologi } \\
\text { - Aliansi global untuk mempertahankan } \\
\text { pertumbuhan }\end{array}$ \\
\hline Target pasar & $\begin{array}{l}\text { - } \text { Lokal } \\
\text { - } \text { Kompetisi dengan } \\
\text { produk di pasar } \\
\text { - Penekanan biaya }\end{array}$ & $\begin{array}{l}\text { - Penguasaan pasar nasional } \\
\text { - Penetrasi pasar memakan } \\
\text { waktu lama } \\
\text { - Produk baru untuk } \\
\text { pelanggan baru }\end{array}$ & $\begin{array}{l}\text { - Pasar global sejak awal } \\
\text { - Jaringan science and techno park } \\
\text { - Penekanan time to market, presale dan } \\
\text { postsale } \\
\text { - Mendidik konsumen teknologi baru }\end{array}$ \\
\hline
\end{tabular}

Sumber: Sambodo, 2006 
Technopreneurship memiliki semangat untuk membangun suatu usaha yang secara karakter adalah integrasi dari kompetensi penerapan teknologi. Pemanfaatan teknologi mutakhir tepat guna dalam pengembangan usaha yang berdasarkan pada jiwa entrepreneur yang mapan akan dapat mengoptimalkan proses sekaligus hasil dari unit usaha yang dikembangkan (Harjono et al., 2013:27). Selain itu, technopreneurship harus sukses pada dua hal, yaitu menjamin bahwa teknologi yang menjadi objek bisnis dapat berfungsi sesuai kebutuhan, target pelanggan dan dapat dijual untuk memperoleh keuntungan serta memberikan manfaat atau dampak secara ekonomi, sosial maupun lingkungan (NCIIA, 2006; dan Suparno et al., 2013).

Technopreneur adalah entrepreneur zaman baru (new age) yang berminat pada teknologi, kreatif, inovatif, dinamis, berani berbeda serta mengambil jalur yang belum dieksplorasi dan sangat bersemangat dengan pekerjaannya (Mintardjo, 2008:229-230). Technopreneur menggabungkan teknologi dan pasar, akhirnya bermuara pada bisnis. Mereka memulai bisnis berbasis inovasi teknologi, harus memiliki sejumlah pendukung diantaranya keinginan kuat untuk mengejar prestasi, kemampuan konseptual dan kekuatan memecahkan masalah tinggi, memiliki wawasan dan cara pikir yang luas, percaya diri tinggi, toleran, berani mengambil risiko, realistis, punya kemampuan interpersonal, dan mengendalikan emosi.

Beragam cara dan model menumbuhkan unit-unit usaha baru yang kental dengan nuansa inovasi teknologi di antaranya model waralaba, model kemitraan, model pendampingan, program inkubator bisnis, serta pola pendidikan kewirausahaan di perguruan tinggi dan sekolah kejuruan yang dikembangkan oleh instansi pemerintah maupun non pemerintah.

Program inkubator dinilai memiliki kelebihan tersediri karena akan tumbuh unit-unit usaha baru yang lebih profesional dalam arti mampu memproduksi barang atau jasa yang lebih berdaya saing. Hal tersebut dimungkinkan karena dalam program inkubator para calon pengusaha dididik untuk menguasai semua aspek bisnis serta dibekali dengan sarana dan modal kerja. Program inkubator juga dinilai efektif dalam membina para entrepreneur muda di India. Dengan program inkubator, para pengusaha yang baru memulai usahanya mendapat dukungan seperti pemasaran, keahlian teknis, pembiayaan dan manajemen bisnis selama fase awal usaha mereka untuk meningkatkan kelangsungan usahanya (Santosh Kumar dan Vinay, 2011).

Oleh karena keunggulan inilah maka sejak tahun 2001 inkubator dijadikan salah satu program Kementerian Koperasi dan UKM kerjasama dengan 13 perguruan tinggi negeri dan swasta. Peraturan Presiden Nomor 27 Tahun 2013 menyebutkan bahwa dalam rangka meningkatkan daya saing nasional perlu ditumbuh kembangkan wirausaha baru yang tangguh, kreatif, dan profesional. Pengembangan inkubator wirausaha bertujuan untuk menciptakan dan mengembangkan usaha baru yang mempunyai nilai ekonomi dan berdaya saing tinggi dan mengoptimalkan pemanfaatan sumber daya manusia terdidik dalam menggerakkan perekonomian dengan memanfaatkan ilmu pengetahuan dan teknologi.

Tujuan pendirian inkubator adalah 1) mengembangkan usaha baru dan usaha kecil yang potensial menjadi usaha mandiri sehingga mampu sukses menghadapi persaingan lokal mapun internasional, 2) mengembangkan promosi kewirausahaan dengan menyertakan perusahaanperusahaan swasta yang dapat memberikan kontribusi pada sistem ekonomi pasar, 3) sarana alih teknologi dan proses komersialisasi hasil-hasil penelitian pengembangan bisnis dan teknologi dari para ahli dan perguruan tinggi, 4) menciptakan peluang melalui pengembangan perusahaan baru, dan 5) aplikasi teknologi di bidang industri secara komersial melalui studi dan kajian yang memakan waktu dan biaya yang relatif murah.

Model inkubator berorientasi pada peningkatan keterampilan. Model ini berperan sebagai ajang untuk peningkatan keterampilan dalam bentuk: a) balai latihan kerja, b) model inkubator berorientasi pada jaringan sistem inovasi, c) model lembaga inkubator yang berperan untuk mendorong lahirnya inovasi para wirausaha, dan d) inkubator yang berorientasi pada pasar ekspor.

Faktor pendukung keberhasilan inkubator adalah: 1) kebijakan pemerintah dan strategi operasional bagi pengembangan inkubator, 2) dukungan pemerintah daerah/regional dalam bentuk pendanaan pembangunan fasilitas fisik inkubator, dan kredit lunak jangka panjang untuk pengelolaan inkubator, 3) dukungan lembaga keuangan baik pemerintah mapun swasta dalam bentuk kredit usaha bagi tenant inkubator, 4) komitmen perguruan tinggi dan lembaga 
penelitian untuk mengembangkan teknologi dan alih teknologi bagi tenant inkubator, 5) sinergi dengan science park atau technology park yang dibangun serentak dengan pembangunan inkubator, 6) pendirian badan hukum inkubator dengan tim pengelola inkubator yang bekerja penuh, profesional dan efisien serta diberikan penghargaan yang layak, 7) pemilihan lokasi yang tepat di pusat kawasan bisns atau di tengah science park atau technology park, 8) dukungan sarana dan prasarana teknologi informasi yang lengkap bagi tenant inkubator, serta 9) penyediaan fasilitas perkantoran pendukung usaha tenant inkubator di bawah satu atap (informasi pasar, modal ventura, bank, dan lain sebagainya).

Provinsi Gorontalo memiliki ragam komoditas unggulan di sektor primer yang potensial untuk investasi termasuk komoditas hortikultura seperti cabe, tomat, bawang merah, pisang, durian, mangga, jahe, dan kunyit (Mopangga, 2012:61). Hal ini dipertegas oleh hasil studi kelayakan identifikasi potensi investasi daerah yang menyimpulkan bahwa hortikultura kelompok sayuran, buahbuahan, tanaman obat/biofarmak, kacang-kacangan, rumput laut, serta ayam buras dan kambing sangat memadai baik secara finansial, pasar, teknik, legal maupun lingkungan bagi masuknya investasi padat modal, padat karya maupun padat teknologi (BID, 2012). Sejumlah kabupaten juga menggalakkan komoditas perkebunan seperti kakao di Boalemo, kopi pinogu di Bone Bolango, dan kelapa sawit di Pohuwato.

Agropolitan dan Etalase Perikanan yang dicanangkan sejak 2006 memang berdampak positif bagi perekonomian daerah. Kontribusinya sigifnikan bagi peningkatan pendapatan, pertumbuhan ekonomi maupun penyerapan tenaga kerja lokal. Persoalannya adalah komoditas unggulan umumnya dijual kepada konsumen lokal, antar pulau maupun luar negeri masih dalam bentuk baku/mentahnya. Sangat minim (bahkan tidak ada) intervensi teknologi atau proses pengolahan untuk memberi nilai tambah produk. Padahal komoditas tersebut bisa diandalkan menjadi kompetensi inti (core competency) industri Gorontalo. Permintaan beberapa negara seperti Malaysia, Filipina, Jepang, dan Korea juga cenderung meningkat. Akibat minimnya kreativitas dan inovasi lokal membuat sulit untuk menemukan produk industri berbahan komoditas unggulan yang dapat dijadikan produk khas daerah (Mopangga et al., 2013:198).
Technopreneurship merupakan wirausaha berbasis teknologi yang hingga saat ini relatif belum berkembang bahkan masih asing di telinga masyarakat Gorontalo. Ini menyebabkan kekayaan dan potensi alam tidak tergarap secara optimal untuk meningkatkan kesejahteraan rakyat. Kalaupun ada pengusaha yang memanfaatkan dan memberdayakan alam maka umumnya hanya bahan mentah dan minim nilai tambah. Dengan memanfaatkan teknologi pengolahan (produksi) dan pemasaran, sumbersumber daya pertanian perkebunan dan perikanan kelautan sebenarnya dapat dimanfaatkan menjadi peluang usaha mikro, kecil, dan menengah (UMKM) terutama bagi generasi muda kreatif dan inovatif serta mau dan mampu merintis usaha.

\section{METODE}

Jenis penelitian ini adalah studi kasus yang menggunakan pendekatan kualitatif deskriptif dengan mengumpulkan dan menggambarkan data yang telah tersedia pada objek yang akan diteliti. Semua kegiatan atau peristiwa berjalan seperti apa adanya, peneliti tidak melakukan manipulasi atau memberikan perlakuanperlakuan tertentu terhadap objek penelitian. Pada studi kasus peneliti mencoba mengggambarkan subjek penelitian di dalam keseluruhan tingkah laku, yakni tingkah laku itu sendiri beserta hal-hal yang melingkunginya. Keuntungan studi kasus adalah dapat mengetahui secara mendalam tentang faktor-faktor yang berpengaruh/sumber belajar wirausahawan.

Pengumpulan data melalui observasi, wawancara, distribusi angket, dan dokumentasi. Penelitian selama 6 bulan sejak Maret sampai September 2015 berlokasi di 6 kabupaten/kota di Provinsi Gorontalo.

Sumber data primer diperoleh dari pelaku usaha mikro kecil menengah kabupaten kota di Provinsi Gorontalo, mahasiswa calon wirausaha yang terdata di Pusat Kreativitas Mahasiswa (PKM), maupun alumni yang telah merintis bisnis. Data sekunder berasal dari Badan Pusat Statistik (BPS) kabupaten kota dan Provinsi Gorontalo, Dinas Koperasi Usaha Mikro Kecil Menengah, Perindustrian dan Perdagangan (Diskumperindag), Badan Lingkungan Hidup Riset dan Teknologi (BLHRD), Badan Pemberdayaan Masyarakat - Pembangunan Desa Tertinggal (BPMPDT). Semua informasi lisan, tertulis, angka-angka (numerik/kuantitiatif) maupun bukan angka (atribut/ kualitatif) menjadi masukan berharga dalam analisis. 
Lulusan perguruan tinggi yang menjadi informan dalam penelitian ini dikategorikan sebagai berikut: 1) masih menganggur, baik yang tergolong kepada pengangguran terbuka maupun pengangguran terselubung (disguised unemployment) dan masih berharap dan berusaha mencari pekerjaan di sektor formal, 2) belum memiliki atau menjalankan usaha/bisnis tetapi bersemangat, minat, dan aktif mencari peluang berwirausaha, 3) sudah memiliki, menjalankan dan atau terlibat dalam usaha/bisnis, baik yang berbasis teknologi (technopreneurship) maupun konvensional (non-technopreneurship).

Kegiatan sosialisasi dan penelitian terkait upaya pengembangan wirausaha baru berbasis teknologi di Provinsi Gorontalo telah kami laksanakan beberapa tahun terakhir ini. Di internal kampus UNG, kami integrasikan pembelajaran berbasis hasil riset (research based learning atau RBL) dan berpusat pada peserta didik (student centered learning atau SCL). RBL dan SCL mengarahkan mahasiswa untuk mengeksplorasi minat dan kemampuannya secara mandiri sehingga tumbuh pemahaman dan motivasi berwirausaha serta kemampuan menulis proposal usaha (perencanaan usaha) yang baik. Mahasiswa belajar berwirausaha berdasarkan teori dan bukti empiris di lapangan (contextual teaching learning) sehingga semakin tertarik untuk berwirausaha, membuka lapangan kerja dan menciptakan pendapatan dan kesejahteraan bagi diri dan masyarakat di lingkungannya kelak.

\section{HASIL}

Provinsi Gorontalo terletak di jazirah utara Pulau Sulawesi antara $0^{\circ} 19^{\prime}-0^{\circ} 57^{\prime}$ Lintang Utara dan $121^{\circ} 23^{\prime}-125^{\circ} 14^{\prime}$ Bujur Timur, berbatasan dengan Provinsi Sulawesi Tengah di sebelah barat, Provinsi Sulawesi Utara di sebelah timur, Laut Sulawesi di sebelah utara, dan Teluk Tomini di sebelah selatan. Memiliki luas $12.435 \mathrm{~km}^{2}$ atau hanya $0,63 \%$ wilayah nusantara dan saat ini memiliki 5 kabupaten yaitu Gorontalo, Boalemo, Pohuwato, Bone Bolango, dan Gorontalo Utara serta Kota Gorontalo (BPS Gorontalo Dalam Angka 2014). Jumlah penduduk sebanyak 1.097.990 jiwa terdiri 550.004 laki-laki dan 547.986 perempuan, laju pertumbuhan penduduk tahun 20102013 mencapai 1,67\%. Kepadatan tertinggi di Kota Gorontalo yakni $2.937 \mathrm{jiwa} / \mathrm{km}^{2}$, sedangkan tingkat kepadatan terendah di Kabupaten Pohuwato hanya 31 jiwa $/ \mathrm{km}^{2}$.
Berdasarkan data Survei Angkatan Kerja Nasional (Sakernas), penduduk usia 15 tahun ke atas yang bekerja di daerah ini berjumlah 449.104 jiwa (Tabel 1.), sedangkan pengangguran berjumlah 19.276 jiwa. Ditahun 2013 pencari kerja yang terdaftar di Dinas Tenaga Kerja dan Transmigrasi Provinsi Gorontalo berjumlah 12.794 orang dan 55,41\% merupakan lulusan universitas.

Tabel 1. Penduduk Berumur 15 Tahun Keatas yang Bekerja Menurut Lapangan Usaha

dan Jenis Kelamin di Provinsi Gorontalo Tahun 2013

\begin{tabular}{lrrr}
\hline \multicolumn{1}{c}{ Lapangan usaha } & Laki-laki & Perempuan & Jumlah \\
\hline Pertanian & 127.875 & 36.762 & 164.637 \\
Industri & 17.994 & 16.179 & 34.173 \\
$\begin{array}{l}\text { Perdagangan, restoran } \\
\text { dan jasa akomodasi }\end{array}$ & 34.789 & 41.627 & 76.416 \\
$\begin{array}{l}\text { Jasa kemasyarakatan, } \\
\text { sosial dan perorangan }\end{array}$ & 36.366 & 53.305 & 89.671 \\
Lainnya & 80.028 & 4179 & 84.207 \\
Jumlah & 297.052 & 152.052 & 449.104 \\
\hline
\end{tabular}

Sumber: BPS Provinsi Gorontalo Dalam Angka, 2014

Jumlah perusahaan industri besar dan sedang di Provinsi Gorontalo tahun 2013 tercatat sebanyak 23 perusahaan dengan 3.279 tenaga kerja, sedangkan banyaknya perusahaan dan tenaga kerja industri mikro kecil tercatat sebanyak 12.921 perusahaan dengan 34.564 tenaga kerja, dapat dilihat pada Tabel 2 .

Tabel 2. Banyaknya Perusahaan dan Tenaga Kerja Industri Mikro Kecil Menurut Jenis Industri di Provinsi Gorontalo Tahun 2010-2013

\begin{tabular}{|c|c|c|c|}
\hline \multicolumn{2}{|c|}{ Jenis Industri } & $\begin{array}{l}\text { Banyaknya } \\
\text { Perusahaan }\end{array}$ & $\begin{array}{c}\text { Tenaga } \\
\text { Kerja }\end{array}$ \\
\hline \multicolumn{2}{|c|}{ Industri pangan } & 5.781 & 13.117 \\
\hline \multicolumn{2}{|c|}{ Industri sandang } & 1.858 & 4.535 \\
\hline \multicolumn{2}{|c|}{ Industri kimia dan bahan bangunan } & 2.882 & 8.503 \\
\hline \multicolumn{2}{|c|}{ Industri logam dan elektronika } & 1.031 & 1.587 \\
\hline \multicolumn{2}{|c|}{ Industri kerajinan } & 1.369 & 6.823 \\
\hline \multirow[t]{4}{*}{ Jumlah } & 2013 & 12.921 & 34.564 \\
\hline & 2012 & 12.360 & 31.910 \\
\hline & 2011 & 11.718 & 30.596 \\
\hline & 2010 & 9.252 & 28.281 \\
\hline
\end{tabular}

Sumber: Dinas Perindustrian, Perdagangan dan Koperasi Provinsi Gorontalo dan GDA tahun 2014. 
Tabel 3. Jumlah dan Prosentase UMKM Menurut Kabupaten Kota di Provinsi Gorontalo Tahun 2013-2014

\begin{tabular}{lllccccc}
\hline & & \multicolumn{2}{c}{ Jenis Usaha Tahun 2013} & \multicolumn{2}{c}{ Jenis Usaha Tahun 2014 } \\
No. & \multirow{2}{*}{ Kabupaten/Kota } & \multicolumn{1}{c}{ Mikro } & Kecil & Menengah & Mikro & Kecil & Menengah \\
& & Jumlah/(\%) & Jumlah/(\%) & Jumlah/(\%) & Jumlah/(\%) & Jumlah/(\%) & Jumlah/(\%) \\
\hline 1 & Kab. Gorontalo & $17.785 /(89,62)$ & $1.593 /(8,03)$ & $468 /(2,36)$ & $18.507 /(86,27)$ & $2.245 /(10,47)$ & $700 /(3,26)$ \\
2 & Kab. Boalemo & $11.169 /(95,06)$ & $487 /(4,14)$ & $94 /(0,80)$ & $11.523 /(92,53)$ & $808 /(6,49)$ & $122 /(0,98)$ \\
3 & Kab. Bone Bolango & $11.169 /(95,06)$ & $487 /(4,14)$ & $94 /(0,80)$ & $11.523 /(92,53)$ & $808 /(6,49)$ & $122 /(0,98)$ \\
4 & Kab. Pohuwato & $3.787 /(77,15)$ & $963 /(19,62)$ & $159 /(3,24)$ & $4.159 /(75,83)$ & $1.118 /(20,38)$ & $208 / 3,79)$ \\
5 & Kab. Gorontalo Utara & $4.985 /(90,26)$ & $455 /(8,24)$ & $83 /(1,50)$ & $5.337 /(86,74)$ & $709 /(11,52)$ & $107 /(1,74)$ \\
6 & Kota Gorontalo & $5.829 /(89,97)$ & $621 /(9,58)$ & $29 /(0,45)$ & $6.929 /(89,31)$ & $789 /(10,17)$ & $40 /(0,52)$ \\
\hline
\end{tabular}

Sumber: Pusat Layanan Data UMKM Dinas Koperasi, Usaha Mikro, Kecil, Menengah, Perindustrian dan Perdagangan Provinsi Gorontalo tahun 2015. Data diolah Januari 2015

Kegiatan wirausaha identik dengan usaha mikro, kecil dan menengah atau disingkat UMKM. UMKM merupakan usaha yang mampu memperluas lapangan kerja dan memberikan pelayanan ekonomi secara luas kepada masyarakat, berperan dalam proses pemerataan dan peningkatan pendapatan masyarakat, mendorong pertumbuhan ekonomi dan mewujudkan stabilitas nasional. UMKM adalah pilar utama ekonomi nasional yang perlu diprioritaskan, memperoleh dukungan, perlindungan dan pengembangan sebagai wujud keberpihakan kepada kelompok usaha ekonomi rakyat tanpa mengabaikan peranan usaha besar maupun korporat.

UMKM juga merupakan satu-satunya sektor ekonomi yang mampu bertahan dari terpaan krisis moneter yang memporak-porandakan struktur ekonomi Indonesia. Seiring dengan era globalisasi saat ini, UMKM dituntut melakukan pembenahan dan perubahan agar dapat meningkatkan daya saingnya. Salah satu upaya yang mutlak dilakukan oleh UMKM agar mampu bersaing adalah inovasi teknologi yang berdaya guna dan berhasil guna untuk peningkatan pendapatan, kesejahteraan, dan perluasan kesempatan kerja.

Berdasarkan jumlah absolut tahun 2013 dan 2014, usaha mikro tertinggi berada di Kabupaten Gorontalo dan terendah di Kabupaten Pohuwato.Usaha kecilyang tertinggi juga di Kabupaten Gorontalo dan terendah di Kabupaten Gorontalo Utara. Usaha menengah juga dipegang Kabupaten Gorontalo dan terendah di Kota Gorontalo. Tetapi dari sisi prosentase, usaha mikro tertinggi di Kabupaten Boalemo dan Bone Bolango (berkisar 92,53\%) menyusul Kota Gorontalo (sekitar 89,31\%).

Dari jumlah 55.702 unit UMKM di Provinsi Gorontalo tahun 2013, ternyata didominasi oleh usaha mikro sebesar 50.120 unit $(89,98 \%)$, usaha kecil hanya 4.638 unit $(8,33 \%)$, dan usaha menengah 944 unit (1,69\%). Di tahun 2014, usaha mikro sebesar 53.386 unit $(87,49 \%)$, usaha kecil 6.330 unit $(10,37 \%)$, dan usaha menengah 1.304 unit $(2,14 \%)$ (Tabel 3.).

Dilihat dari sebaran menurut kabupaten/kota ternyata proporsi paling kecil untuk usaha mikro terdapat di Kabupaten Pohuwato. Proporsi usaha kecil terendah terdapat di Kabupaten Boalemo dan Bone Bolango, sedangkan usaha menengah, prosentase terkecil di Kota Gorontalo. Kelima kabupaten di Provinsi Gorontalo secara geografis dan sosio kultural sangat bergantung kepada aktivitas ekonomi di sektorpertanian, peternakan, dan perikanan. Hampir semua daerah menghasilkan padi sawah, jagung dan kelapa dalam, ternak ayam dan sapi, serta aneka jenis ikan laut. Hal ini menyebabkan pengembangan wirausaha, UMKM dan sektor-sektor alternatif biasanya diarahkan terkait dengan pertanian peternakan dan perikanan kelautan.

Berdasarkan wawancara lapangan ditemukan bahwa pelaku usaha mikro kecil menengah cenderung tidak tertarik untuk berkreasi atau melakukan inovasi tertentu agar terjadi perbaikan atau peningkatan kualitas produknya. Mereka yang bergerak dibidang usaha bahan makanan olahan dan komoditas pertanian berargumen bahwa bila melakukan inovasi teknologi atas produknya maka akan mengeluarkan biaya 
ekstra. Akibatnya margin keuntungan menipis bahkan beresiko rugi karena inovasi produk tersebut tidak berdampak menaikkan kuantitas produksi maupun harga jual per unit. Saat yang sama luas pasar sasaran (skala ekonomi) lokal Gorontalo sangat terbatas dan produknya kalah bersaing bila di ekspor atau dikirim ke luar daerah. Inovasi produk maupun proses produksi dilakukan hanya untuk keperluan pameran/ eksebisi ditingkat regional dan nasional, bukan untuk peningkatan mutu produk, diversifikasi dan efisiensi dalam jangka pendek maupun peningkatan produksi secara berkelanjutan, peningkatan omset, laba, serta perluasan usaha dalam jangka panjang.

Berdasarkan data sekunder yang dihimpun dari beberapa instansi teknis yang kompeten dalam urusan UMKM ternyata tidak mengklasifikasikan dengan jelas antara technopreneurship dengan usaha tradisional dalam analisis data maupun publikasinya. Ini menyulitkan pemetaan jenis usaha yang ramah IPTEK dengan yang bersifat tradisional, sekaligus berpotensi menghambat proses alih teknologi, transfer pengetahuan, keterampilan manajerial maupun efektivitas dan permodalan.

Perguruan tinggi turut bertanggung jawab dalam mendidik dan mempersiapkan para lulusannya dan memberikan motivasi agar mereka berani memilih berwirausaha secara profesional. Jiwa wirausaha dapat ditumbuhkan mulai dari lingkungan rumah dan sekolah dengan mendapat bimbingan dari para pembina (Okorie, 2014). Pendapat lainnya menyebutkan bahwa Perguruan tinggi idealnya harus memiliki disain pembelajaran kewirausahaan yang mampu mendidik mahasiswa pada kemandirian, jiwa inovatif, keberanian mengambil risiko, keuletan, dan kemampuan negosiasi (Wahyuningsih dan Qamari, 2011).

Dengan jiwa wirausaha yang terus ditumbuhkembangkan di kalangan mahasiswa, diharapkan dapat meningkatkan orientasi wirausaha mereka. Berbagai penelitian membuktikan bahwa kunci keberhasilan usaha dikendalikan oleh orientasi wirausaha pengusahanya (Wiklund dan Shepherd, 2005; Nur et al., 2014; Islam dan Obaidullah, 2011).

Tridharma yang dijalankan sivitas akademika terutama dosen adalah pendidikan pengajaran, penelitian, dan pengabdian kepada masyarakat hendaknya tidak hanya berorientasi menghasilkan tenaga kerja unggul siap pakai, berdaya saing, dan berakhlak mulia tetapi lebih dari itu yaitu generasi yang mampu menciptakan lapangan kerja baru melalui daya kreasi dan inovasi teknologi sekaligus menangkap peluang pasar, kebutuhan dunia usaha dan dunia industri.

Dalam pernyataan visi, misi, tujuan, dan sasaran pengembangan institusi khusus dibidang softskill kemahasiswaan, Rektor Universitas Negeri Gorontalo telah membentuk Pusat Kegiatan Mahasiswa yang khusus menangani pembinaan kemahasiswaan dan Program Kreativitas Mahasiswa (PKM) melalui SK Nomor 3B/UN47/LL/2013. Pusat Kegiatan Mahasiswa secara reguler melaksanakan pembinaan kewirausahaan mahasiswa dan program pendampingan. Setiap tahun UNG memberikan kesempatan kepada mahasiswa untuk berpartisipasi dalam kegiatan program kegiatan mahasiswa dengan mengirimkan proposal penelitian, gagasan tulis dan kewirausahaan. Dengan adanya kegiatan pendampingan bagi mahasiswa ini maka setiap tahunnya UNG mendapatkan bantuan dana untuk pengembangan kewirausahaan dan bantuan dana penelitian dari Ditjen DIKTI baik itu untuk PKM, Pekan Ilmiah Nasiona (PIMNAS) ataupun program hibah desa.

Rektor bersama segenap jajaran pimpinan Universitas Negeri Gorontalo telah mengembangkan dan mewujudkan pemikiran bahwa pendidikan kewirausahaan bagi mahasiswa merupakan bagian integral sistem pendidikan tinggi sehingga mulai tahun 2012, PKM mengembangkan metode pengajaran kewirausahaan dengan mengadakan Kuliah Umum Kewirausahaan bagi mahasiswa secara regular setiap semester dengan narasumber para praktisi bisnis berskala nasional maupun pengusaha lokal. Dalam kurun waktu 3 tahun terakhir ini terdapat beberapa tokoh yang sudah menyampaikan kuliah umum antara lain Rahmat Gobel, Dahlan Iskan, Harry Tanoesudibyo, Sandiaga Uno, Erwin Aksa, Fadel Muhammad, dan banyak lagi yang sampai saat ini jumlahnya sudah hampir mencapai 50 orang narasumber.

Upaya yang telah dilakukan mulai membuahkan hasil dengan semakin banyaknya mahasiswa yang melakukan aktifitas bisnis serta mengikutsertakan produknya dalam entrepreneurship expo baik di lingkungan kampus maupun di luar kampus. Guna memberikan fasilitasi yang lebih bagi mahasiswa yang mulai berbisnis ini, maka rektor resmi mendirikan lembaga entrepreneurship centre dalam struktur Lembaga Pengabdian Masyarakat bernama Pusat Inkubator Bisnis. 
Semenjak tahun 2013 hingga sekarang Pusat Inkubator Bisnis diberi kepercayaan mengelola kegiatan Program Mahasiswa Wirausaha (PMW) dengan kegiatan pelatihan bisnis bagi mahasiswa, melakukan seleksi proposal bisnis, menyalurkan modal untuk seed capital bisnis serta melakukan pendampingan bagi mahasiswa yang berbisnis. Di tahun 2013 terdapat sebanyak 36 unit usaha mahasiswa telah diberi modal sebagai seed capital untuk mengembangkan bisnisnya. Di tahun 2014 juga telah dibiayai sebanyak 45 unit usaha mahasiswa dengan seed capital yang meningkat. Pada tahun 2015 jumlah mahasiswa yang berminat menjadi pengusaha makin tinggi. Hal ini terlihat dari sedikitnya 500 orang mahasiswa yang mengajukan proposal bisnis dan total seed capital yang disalurkan mencapai diatas 700 juta rupiah. Kelompok mahasiswa wirausaha umumnya bergerak dalam usaha agro industri, makanan basah olahan, makanan ringan dalam kemasan, asesoris/ fashion, ternak ayam, jasa warnet, fotokopi, binatu dan kegiatan bisnis yang permintaan konsumennya cenderung meningkat.

Misi memperkuat wirausaha mahasiswa juga dilaksanakan dosen melalui inovasi pembelajaran. Disamping perkuliahan teoritis dalam ruang kelas, pembelajaran kontekstual dilaksanakan dalam bentuk kunjungan lapangan (visit bisnis) ke sentra-sentra UMKM dan industri rumah tangga. Hasil interaksi dengan pelaku usaha kemudian dituangkan dalam makalah yang akan dipresentasikan dan didiskusikan di kelas. Mahasiswa menjadi semakin kritis karena mampu menyampaikan gagasan bisnis dan alternatif solusi dari permasalahan dan pertanyaan yang diajukan kawan sekelasnya, begitupun sebaliknya. Intinya, terbangun pembelajaran yang berpusat pada peserta didik (student centered learning/SCL) dan memberi stimulan kepada mahasiswa untuk termotivasi menjadi wirausahawan sukses. Karakter unggul dari wirausahawan sukses bisa diadopsi melalui tahapan perubahan cara berpikir, sikap dan kebiasaan. Hal itu memerlukan proses belajar dan latihan yang terus-menerus. Untuk menjadi wirausahawan sukses diperlukan "jam terbang belajar" yang tinggi dengan menggunakan "model belajar" kisah sukses tokohtokoh wirausahawan atau pengusaha yang dapat ditemui di lingkungan sekitar.

Salah satu contoh keterlibatan aktif Universitas Negeri Gorontalo dalam menumbuhkembangkan wirausaha berbasis teknologi adalah kemitraan dengan Pemerintah Kabupaten Gorontalo Utara dalam Program Desa Industri Mandiri (DIM) Berbasis Pertanian Organik. DIM merupakan bentuk hilirisasi industri hijau menciptakan wirausaha baru di pedesaan yang mengembangkan pertanian organik berbasis sumberdaya lokal. Konsep DIM melalui inovasi bio teknologi pertanian diharapkan mendukung eksistensi industri kecil dan koperasi yang ramah lingkungan secara berkelanjutan. Konsep organik yang diterapkan pada pertanian, perikanan dan peternakan merupakan jawaban atas kebutuhan masyarakat terhadap bahan pangan alamiah (back to nature). Pembentukan DIM melibatkan semua stakeholder bidang pertanian dan bidang lain yang menunjang dari aspek penyediaan sarana prasarana, bahan baku, peralatan, pemasaran, pendidikan dan kesehatan yang berbasis potensi sumber daya lokal. Implementasinya, DIM memberdayakan masyarakat baik dari industri hulu, antara dan hilir, sehingga melahirkan wirausaha baru dari kalangan masyarakat dan mengurangi pengangguran pedesaan.

\section{PEMBAHASAN}

Pentingnya technopreneurship dewasa ini berkenaan dengan keterikatannya pada ilmu dan teknologi. Ketika negara menggunakan pendekatan peningkatan kemampuan teknologi sebagai pendorong peningkatan produksi nasional dan dalam banyak negara sebagai strategi competitive advantage, maka technopreneurship adalah program yang termasuk didalamnya sebagai bagian integral dari peningkatan budaya (culture) kewirausahaan. Technopreneurship perlu mengkolaborasikan budaya dan konsepsi, yaitu budaya inovasi, kewirausahaan, dan kreativitas, serta konsep inkubator bisnis, penelitian, pengembangan, knowledge management dan learning organization, yang didukung oleh kapabilitas wirausahanya sendiri, koneksitas dan kolaboratif.

Strategi yang kuat serta arah yang jelas perlu dikembangkan untuk memberikan landasan bagi berkembangnya technopreneurship khususnya provinsi dan kabupaten kota di Gorontalo. Perlu kerjasama yang erat dari pelaku usaha sebagai penggagas bisnis, perguruan tinggi, dan lembaga penelitian sebagai pusat inovasi teknologi baru dan pihak perbankan yang kompeten dalam pendanaan serta pemerintah sebagai pembentuk kebijakan ekonomi agar dapat memberikan kebijakan yang kondusif. 
Usaha mikro kecil dan menengah memberi dampak positif bagi perkembangan ekonomi Gorontalo dalam membuka lapangan kerja baru dan meningkatkan pendapatan masyarakat. Bila dibandingkan dengan UMKM di Pulau Jawa, jelas UMKM di Gorontalo masih kalah dari sisi jumlah unit usaha, kuantitas, maupun kualitas produk yang dihasilkan. Karakteristik UMKM di Gorontalo masih sangat bertumpu pada komoditas pertanian yang minim proses industri pengolahan. Akibatnya nilai tambah produk rendah dan kalah bersaing bila hendak memasuki pasar nasional maupun ekspor. Hal ini turut memperlemah daya kreasi, inovasi, dan semangat UMKM lokal. Kegiatan wirausaha atau UMKM yang menerapkan inovasi teknologi dalam pengembangan bisnisnya di Gorontalo belum dapat diidentifikasi dengan tepat, baik dari aspek kualifikasi maupun jumlahnya karena memang belum terdapat definisi dan upaya terencana dan terstruktur untuk membangun dan mengarahkan tumbuhnya UMKM berdasarkan pemanfaatan inovasi teknologi. Hal ini disadari dapat menghambat proses alih teknologi, transfer pengetahuan, keterampilan manajerial maupun efektivitas dan penggunaan modal usaha yang berdampak pada daya saing UMKM itu sendiri.

Universitas Negeri Gorontalo sebagai perguruan tinggi negeri terkemuka di wilayah utara jazirah Sulawesi ini wajib mengambil peran dalam memajukan penguasaan dan penerapan ilmu pengetahuan, teknologi dan bisnis di Provinsi Gorontalo. Pengembangan wirausaha mahasiswa menjadi pilar penting dalam penyelenggaraan tridharma termasuk membangun jaringan kemitraan dengan pemerintah, instansi teknis di daerah, badan-badan usaha swasta maupun perorangan yang peduli pada peningkatan jumlah dan kualitas wirausaha baru berbasis inovasi teknologi.

Dalam menjawab tantangan makin meningkatnya pengangguran intelektual dan menghadapi pemberlakuan Masyarakat Ekonomi ASEAN, maka Rektor UNG bersama seluruh jajaran terus berupaya memperkuat pondasi wirausaha melalui Program Kreativitas Mahasiswa, Program Mahasiswa Wirausaha, dan Pusat Inkubator Bisnis Kemitraan dengan pemerintah daerah, dunia usaha dan dunia industri juga mulai membuahkan hasil menggembirakan dari Program Desa Industri Mandiri Berbasis Pertanian Organik di Kabupaten Gorontalo. Ini merupakan best practice pembelajaran kontekstual, pemberdayaan masyarakat, dan pengembangan industri mikro, kecil, dan menengah di Provinsi Gorontalo.

\section{KESIMPULAN}

Rendahnya daya saing produk UMKM Provinsi Gorontalo disebabkan masih rendahnya penguasaan teknologi dikalangan pelaku usaha. Bila ada inovasi teknologi sifatnya temporer, hanya untuk keperluan pameran/eksebisi ditingkat regional dan nasional, bukan untuk peningkatan mutu produk, diversifikasi dan efisiensi dalam jangka pendek maupun peningkatan produksi secara berkelanjutan, peningkatan omset, laba, serta perluasan usaha dalam jangka panjang.

Instansi teknis yang kompeten dalam urusan UMKM ternyata tidak mengklasifikasikan dengan jelas antara technopreneurship dengan usaha tradisional dalam analisis data maupun publikasinya. Ini menyulitkan pemetaan jenis usaha yang ramah IPTEK dengan yang bersifat tradisional, sekaligus berpotensi menghambat proses alih teknologi, transfer pengetahuan, keterampilan manajerial, maupun efektivitas dan permodalan.

Program Desa Industri Mandiri Berbasis Pertanian Organik Kemitraan UNG - Gorontalo Utara merupakan best practice untuk memperluas dan memperkuat technopreneur unggul di daerah. Inovasi ditingkat petani, peternak, dan kelompok usaha bersama (KUB) cukup efektif meningkatkan pendapatan, mengurangi pengangguran, transfer IPTEK, dan membuka pasar baru bagi produk.

Minat mahasiswa untuk menjadi wirausaha inovatif (technopreneur) dapat ditingkatkan melalui research based learning dan student centered learning. RBL dan SCL mengarahkan mahasiswa untuk mengeksplorasi minat dan kemampuannya secara mandiri sehingga tumbuh pemahaman dan motivasi berwirausaha serta kemampuan menulis proposal usaha (rencana usaha) yang baik.

\section{UCAPAN TERIMA KASIH}

Puji dan syukur kehadirat Allah SWT serta ungkapan terima kasih dan penghargaan setinggitingginya penulis sampaikan kepada Yang Terhormat Direktorat Penelitian dan Pengabdian Kepada Masyarakat (DP2M) Dikti Kementerian Ristek 
dan Dikti di Jakarta yang memfasilitasi pendanaan penelitian ini melalui Hibah Desentralisasi tahap pertama Tahun 2015. Besar harapan kami penelitian ini tetap difasilitasi pada tahap kedua yaitu Tahun 2016.

Kami juga berterima kasih kepada Rektor Universitas Negeri Gorontalo yang senantiasa mendorong lahirnya peneliti-peneliti yang produktif dan unggul di kampus merah maron.Kepada Ketua Lemlit dan Dekan Fakultas Ekonomi dan Bisnis UNG, kami ucapkan terima kasih atas bantuannya dalam memudahkan penyampaian usulan hingga laporan penelitian ini baik secara manual maupun online.

\section{DAFTAR PUSTAKA}

BID. 2012. Studi Kelayakan Identifikasi Potensi Investasi Daerah. Badan Investasi Daerah Provinsi Gorontalo.

BPS. 2015. Gorontalo dalam Angka 2014. BPS Provinsi Gorontalo.

Ciputra. 2009. Ciputra Quantum Leap Entrepreneurship: Mengubah Masa Depan Bangsa dan Masa Depan Anda (edisi ke-4). Jakarta: Elex Media Komputindo.

Depositario D. P. T., Aquino N. A., \& Feliciano K.C. 2011. Entrepreneurial Skill Development Needs Of Potential Agri-Based Technopreneurs. ISSAAS, 17(1): 106-120.

Harjono, Ardi Widyatmoko, dan Nurhidayat, Taufik. 2013. Pembelajaran Kewirausahaan Politama. Prosiding KNIT RAMP-IPB: 27-32.

Islam, Md. Aminul, Khan. M. A., \& Obaidullah, A. Z. 2011. Effect of Entrepreneur and Firm Characteristics on the Business Success of Small and Medium Enterprises (SMEs) in Bangladesh. International Journal of Business and Management, 6(3): 289-299.

Kementerian Perdagangan RI. 2014. Menjadi Pemenang pada Masyarakat Ekonomi ASEAN 2015. Makalah disampaikan pada Edukasi Publik AEC Grand Q Hotel Gorontalo 23 April 2014.

Kumar, Santosh A. N. \& Vinay K. B.. 2011. Technology Business Incubators - India's Rejuvenating Scenario in Entrepreneurship Development. Journal of Information, Knowledge and Research in Business Management and Administration, 1(2): 9-14.

Mintardjo, Christoffel. 2008. Teknopreneur sebagai Entrepreneur Abad 21: Suatu Pengantar. Jurnal FORMAS, 1(4): 228-237.
Mopangga, Herwin. 2008. Penerapan Teknologi dan Transformasi Kelembagaan pada Masyarakat Pedesaan di Indonesia. Jurnal Ilmiah Agropolitan, 1(1): 29-39.

Mopangga, Herwin. 2012. Rancang Bangun Kawasan Agribisnis Hortikultura Provinsi Gorontalo. Jurnal Agribisnis Terpadu, 5(1): 46-62.

Mopangga, Herwin et al. 2013. Komoditas Unggulan Lokal sebagai Sumber Inovasi dan Wirausaha Mahasiswa; Pengalaman dari Gorontalo. Prosiding KNIT RAMP-IPB: 195-202.

Nasrun, M. A. 2010. Mengapa Banyak Sarjana yang Menganggur?. Suara Merdeka, 25 September.

NCIIA. 2006. Invention to Venture: Workshop in Technology Entrepreneurship. Madison: National Collegiate Inventors and Innovators Alliance.

Niode, I. Y. 2007.Wirausaha Sebagai Alternatif Solusi Masalah Pengangguran. Jurnal Inovasi, 4(1): 91-99.

Nur, N. et al. 2014. Entrepreneurship Orientation, Market Orientation, Business Strategy, Management Capabilities On Business Performance; Study At Small And Medium Enterprise Printing In Kendari. International Journal of Business and Management Invention, 3(12): 8-17.

Okorie N. N. et al. 2014. Technopreneurship: An Urgent Need in The Material World for Sustainability in Nigeria. European Scientific Journal, 10(30): 1857-7881.

Ono, Suparno et al. 2013. Peningkatan Minat Technopreneurship Melalui Workshop Satu Hari. Prosiding KNIT RAMP-IPB: 131-139.

Sambodo, Amir. 2006. Makalah Seminar Pengembangan Technopreneurship. Jakarta.

Setiadi, U. 2008. Suatu Pemikiran Mengenai Pendekatan Kembali Antara Dunia Pendidikan S1 Manajemen Dengan Dunia Kerja. Prosiding Konferensi Merefleksi Domain Pendidikan Ekonomi dan Bisnis. Salatiga.

Soegoto, Eddy Soeryanto. 2009. Entrepreneurship; Menjadi Pebisnis Ulung. Jakarta: Elex Media Komputindo.

Sosrowinarsidiono. 2010. Membangun Sinergi Teknologi Dengan Kemampuan Kewirausahaan Guna Menunjang Kemandirian Bangsa. Munas Asosiasi Perguruan Tinggi Ilmu Informatika. Bandung: Politelkom.

Sudarsih, Endang. 2013. Pendidikan Technopreneurship: Meningkatkan Daya Inovasi Mahasiswa Teknik dalam Berbisnis. Prosiding KNIT RAMP-IPB: 56-63. 
Wahyuningsih, Sri Handari dan Qamari, Ika Nurul. 2011. Eksplorasi Urgensi Pembelajaran Kewirausahaan di Perguruan Tinggi. Prosiding Seminar Internasional dan Call for Papers “Towards Excellent Small Business": 236-258.
Wiklund, Johan \& Shepherd, Dean. 2005. Entrepreneurial Orientation and Small Business Performance: A Configurational Approach. Journal of Business Venturing, 20(1): 71-91. 